\title{
Performance Evaluation of a Down Draft Double Chamber Pyrolysis Reactor under Field Conditions
}

\author{
A.M.Y.W. Alahakoon* A.K. Karunarathna ${ }^{1}$ and R.S. Dharmakeerthi ${ }^{2}$ \\ Postgraduate Institute of Agriculture \\ University of Peradeniya \\ Sri Lanka
}

\begin{abstract}
Sequestration of carbon through production of biochar has been recognized as a feasible approach to combat global warming. The application of biochar production technology in industrial scale is still new to developing countries due to high complexity and specificity of pyrolysis technology. Therefore, this study aimed to evaluate a small scale pyrolysis unit (Down Draft Double Chamber pyrolysis reactor - DDDC reactor) to be used in continuous biochar production with the use of paddy husk as the both feedstock and fuel material. The temperature variation, syngas composition and energy value, mass and energy balances of the DDDC reactor were evaluated through field trials. The average temperature varied from $330^{\circ} \mathrm{C}$ to $560{ }^{\circ} \mathrm{C}$ from bottom to the top of the reactor fulfilling the temperature requirement for pyrolysis. However, fluctuations in temperature were observed during trials due to low energy supply through paddy husk as the fuel. This suggested a need of using a supplementary fuel source to operate the reactor. The biochar recovery of the reactor was $32 \%$ (dry matter basis) and the average biochar production rate was $1 \mathrm{~kg} / \mathrm{h}$ for material input of $4.42 \mathrm{~kg} / \mathrm{h}$ of paddy husk and $0.77 \mathrm{~kg} / \mathrm{h}$ of coconut shell as fuel sources. The average raw syngas composition ( $\mathrm{v} / \mathrm{v}$ ) was $20.78 \% \mathrm{CO}, 13.3 \% \mathrm{CO}_{2}, 3.87 \% \mathrm{CH}_{4}, 0.3 \% \mathrm{C}_{n} \mathrm{H}_{\mathrm{m}}, 6.91 \%$ $\mathrm{H}_{2}, 0.68 \% \mathrm{O}_{2}$, and $54.16 \% \mathrm{~N}_{2}$ with an average energy content of $5.34 \mathrm{MJ} / \mathrm{m}^{3}$. This study showed the potential for optimizing and upscaling a continuous mode paddy husk pyrolysis reactor for industrial applications.
\end{abstract}

Keywords: biochar, paddy husk, pyrolysis, pyrolysis reactor, syngas quality, temperature variation

\section{INTRODUCTION}

Ever increasing energy demand and negative impacts of burning fossil fuels have driven the attention to explore new potentials for energy production. Thermochemical reactions of biomass and energy generation, such as pyrolysis, is one of the feasible methods discussed during the recent past (Panwar, 2009). Less complex operation process and low operation cost made the pyrolysis a widely applied tool as an energy alternative (Aziz et al., 2018). There are many advances in the technologies related to pyrolysis. However, the availability of tailor-made technologies for developing countries are lacking (Woolf et al., 2017). Especially, agricultural countries produce ample amount of agricultural wastes that can be used as alternative energy sources through biomass pyrolysis. However, there is a need to acquire safe, efficient pyrolysis technologies for an affordable cost.

1 Department of Agricultural Engineering, Faculty of Agriculture, University of Peradeniya, Sri Lanka.

2 Department of Soil Science, Faculty of Agriculture, University of Peradeniya, Sri Lanka.

* Corresponding author: yushaniamyw@gmail.com 
Despite energy generation, biochar production through pyrolysis has drawn considerable attention in the field of agriculture as a soil amendment and as an approach for atmospheric carbon sequestration (Woolf, et al., 2017). Therefore, the production of biochar with available agricultural wastes and application to the agricultural fields have identified as successful methods for resource recovery through pyrolysis (Sylva et al., 2014; Putun et al., 2004; Mullen, et al., 2010). Biochar production industry in Sri Lanka is being mostly operated in medium or small scale with agro-based biomass materials. Various studies have been conducted during recent years to develop and promote the biochar production in Sri Lanka. Biomass sources such as gliricidia woods, paddy husk, refused tea (Amarasinghe et al., 2016), coconut shell, coconut husk, corn cobs, rubber wood and biomass fraction of municipal solid waste (Bandara et al., 2016; Dharmakeerthi, 2014; Dharmakeerthi et al., 2014) were used with these experiments. Most of these developed technologies are suitable with batch operations and there is a need to introduce continuous type pyrolysis technologies, which are more suitable for commercial applications. Auger type (Brown, 2009; Brassard, et al., 2017), fluidized bed (Boateng, et al., 2007; Kersten, et al., 2005), rotating cone reactors (Westerhout, et al., 1998; Wagenaar, et al., 1995) are some of the popular technologies that are developed previously. It is also possible to use the down draft technology to support continuous pyrolysis. In the down draft technology, feedstock materials are transferred through a vertical reactor from top-to-bottom while supplying heat and pyrolysed products are taken out from the bottom of the reactor. This study was conducted to design and fabricate a continuous type Down Draft Double Chamber (DDDC) pyrolyser reactor and evaluate the performance of that reactor for biochar production using paddy husk as both the feedstock and energy source.

\section{METHODOLOGY}

\section{System Design}

A continuous type small scale DDDC reactor was designed and fabricated to evaluate the performance of the down draft, double chamber technology to pyrolyse paddy husk. General specifications of the reactor are summarized in the Table 1 .

Table 1. General specifications of the Down Draft Double Chamber reactor

\begin{tabular}{ll}
\hline Specification & Description \\
\hline Reactor type & Continuous type \\
Portability & Stationary \\
Feedstock & Paddy husk \\
Fuel type & Paddy husk and coconut shell (supplementary) \\
Heat transfer rate & Slow \\
Method of heating & Indirect heating \\
Loading and unloading of material & Manual \\
\hline
\end{tabular}


Schematic diagrams of the designed DDDC reactor is shown in the figure 1 and figure 2.This DDDC reactor mainly consists of two chambers where inner small chamber (diameter $=30 \mathrm{~cm}$ and height $=88 \mathrm{~cm}$ ) used as the pyrolysis chamber and outer larger chamber (diameter $=50 \mathrm{~cm}$ and height $=106 \mathrm{~cm}$ ) used for fuel combustion. Fuel (paddy husk) is supplied through a feeder with an air flow and the combusted hot air flows through the exhaust gas outlet. Paddy husk for the pyrolysis is fed through the feedstock inlet and the produced biochar is taken out from the biochar outlet through an auger conveyor. Combusted fuel ash is taken out from the ash outlet and the produced syngas is transferred to a syngas purifying system via syngas outlet. Syngas was purified by passing through a bubbling scrubber system where a $\mathrm{Ca}(\mathrm{OH})_{2}$ solution was used as the scrubbing media.

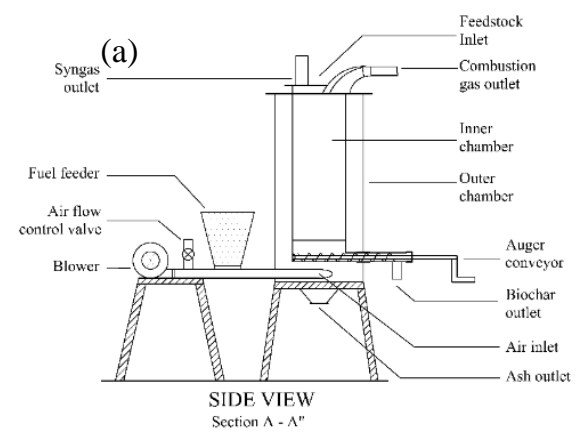

(b)

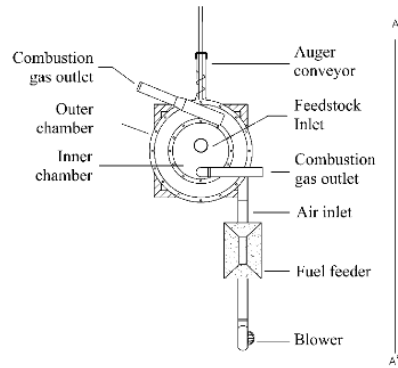

PLAN VIEW

Figure 1. (a) Cross section and (b) plan view diagrams of the Down Draft Double Chamber reactor

Paddy husk was collected from the small-scale rice mills near Kandy-Gampola (Gelioya area), Sri Lanka. It was a mixture of paddy husk from different rice varieties. Other than that, coconut shells were used as a supplementary fuel source during the field trials.

\section{Operation mechanism}

This reactor was designed to manufacture biochar in continuous mode. During the field operations, the biochar production was done continuously and produced biochar was taken out approximately at $20 \mathrm{~min}$ intervals through the auger conveyor. The paddy husk resident time inside the reactor was approximately 30 minutes. The feeding of paddy husk was done batch wise when the inner chamber was emptied. The fuel paddy husk was fed continuously to the reactor after fluidizing with an average air supply of $0.01 \mathrm{~m}^{3} / \mathrm{s}$ with a 4 " air blower. Few coconut shells were added to the outer combustion chamber $(0.77 \mathrm{~kg} / \mathrm{hr})$ in order to maintain the required temperature. The DDDC reactor together with the bubbling scrubber unit is shown in Figure 2. 


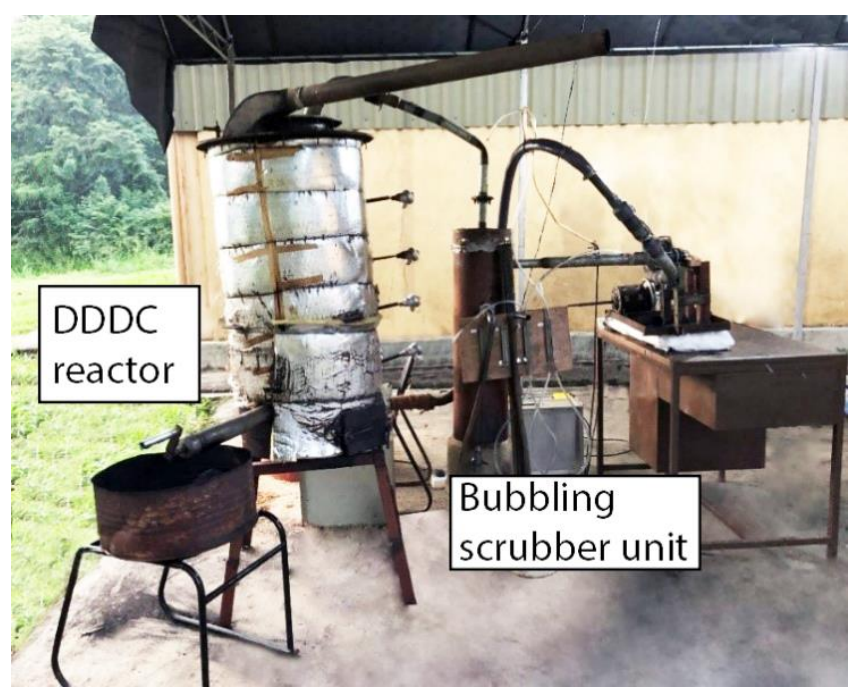

Figure 2. The DDDC reactor during the field operations at Meewathura farm premises

\section{Measurement of parameters}

Reactor performance was assessed by measuring temperatures, conducting mass balance and analysing gas compositions during the field trials. Four K-type thermocouples were inserted to the outer chamber along the vertical axis of the reactor (Port 1 to 4, Figure 3) In addition, Campbell CR1000 data-logger was used for the temperature data recording. The composition and the energy values of syngas and exhaust gas were measured using a portable syngas analyser (Gasboard 3100P with $0.02-0.03 \% \mathrm{v} / \mathrm{v}$ precision). The measurement of gas was done by using three gas outlet ports (Figure 4). Ports 5, 6 and 7 were used to measure the exhaust gas, raw syngas measurement and cleaned syngas measurement, respectively. Volume $\%$ of constituents in exhaust and syngas such as $\mathrm{CO}, \mathrm{CO}_{2}, \mathrm{O}_{2}, \mathrm{~N}_{2}, \mathrm{CH}_{4}, \mathrm{C}_{\mathrm{n}} \mathrm{H}_{\mathrm{m}}$ and $\mathrm{H}_{2}$, and composite heating value $\left(\mathrm{MJ} / \mathrm{m}^{3}\right)$ were frequently recorded. 


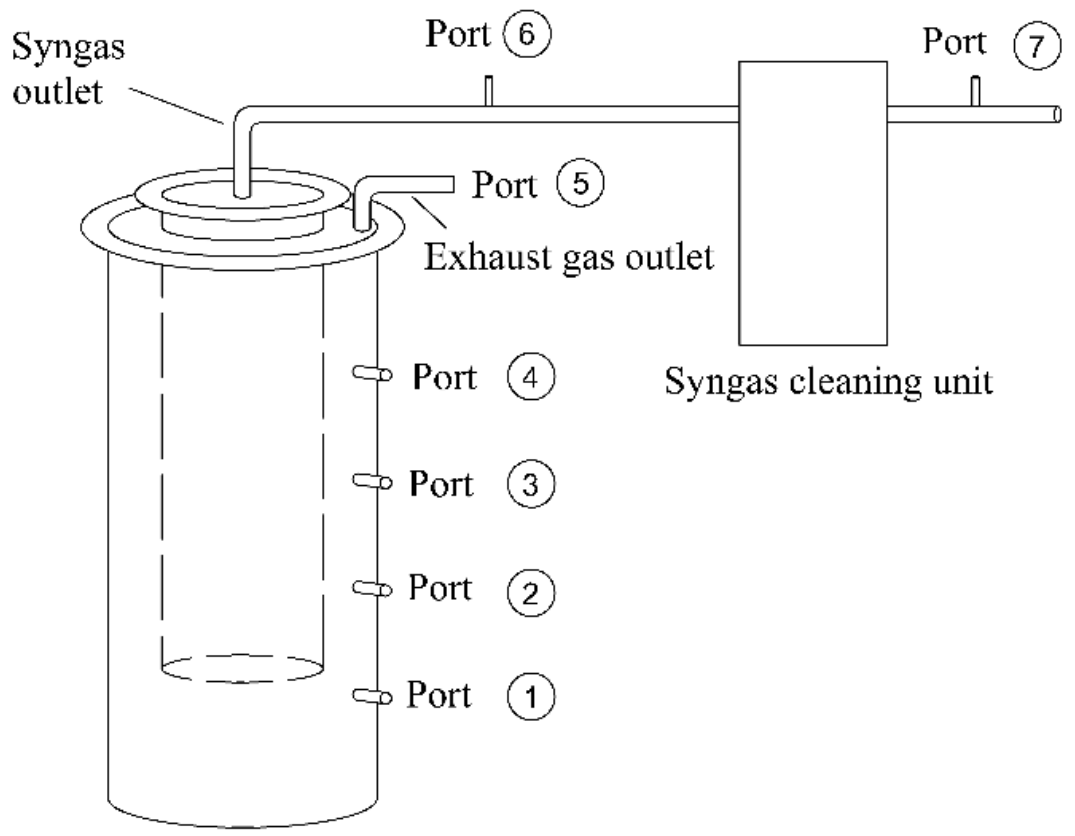

Figure 3. Thermocouple placement and syngas measuring ports in the DDDC reactor

The biochar recovery and the energy calculations were done by using the following equations.

Biochar recovery $(\%)=\frac{\text { Weight of obtained biochar }(g)}{\text { Weight of the used biomass }(g)} * 100$

Energy content of each biomass material used was evaluated from the equation 2 and the energy balance (equation 3) was used to estimate the energy losses through the reactor.

$\left[\begin{array}{c}\text { Energy content of } \\ \text { biomass material }(k J)\end{array}\right]=\left[\begin{array}{c}\text { Heating value of } \\ \text { the material }(k J / k g)\end{array}\right] \times$ Used mass $(\mathrm{kg})$

$$
Q_{\text {Input }}=Q_{\text {output }}
$$

$\left[\begin{array}{l}\text { Energy in } \\ \text { Feedstock }\end{array}\right]+\left[\begin{array}{c}\text { Exetrnal energy } \\ \text { from fuel }\end{array}\right]=\left[\begin{array}{c}\text { Energy in } \\ \text { biochar }\end{array}\right]+\left[\begin{array}{c}\text { Energy in } \\ \text { gaseous products }\end{array}\right]+\left[\begin{array}{c}\text { Energy in } \\ \text { Bio }- \text { oil }\end{array}\right]+[$ Losses $]$

\section{RESULTS AND DISCUSSION}

\section{Temperature variations}

The temperature data obtained from the reactor during the field trials showed a gradient of the temperature from bottom to the top of the reactor where there was an average temperature of $560{ }^{\circ} \mathrm{C}$ near the bottom of the reactor and an average temperature of $330^{\circ} \mathrm{C}$ near the top of 
the reactor (Figure 4). The temperature requirements for the different stages of the pyrolysis process and their relationship with the reactor operating mechanism are given in the Table 2 . Accordingly, the temperature gradient of the reactor fulfilled the temperature requirement to complete the different stages of the pyrolysis process.

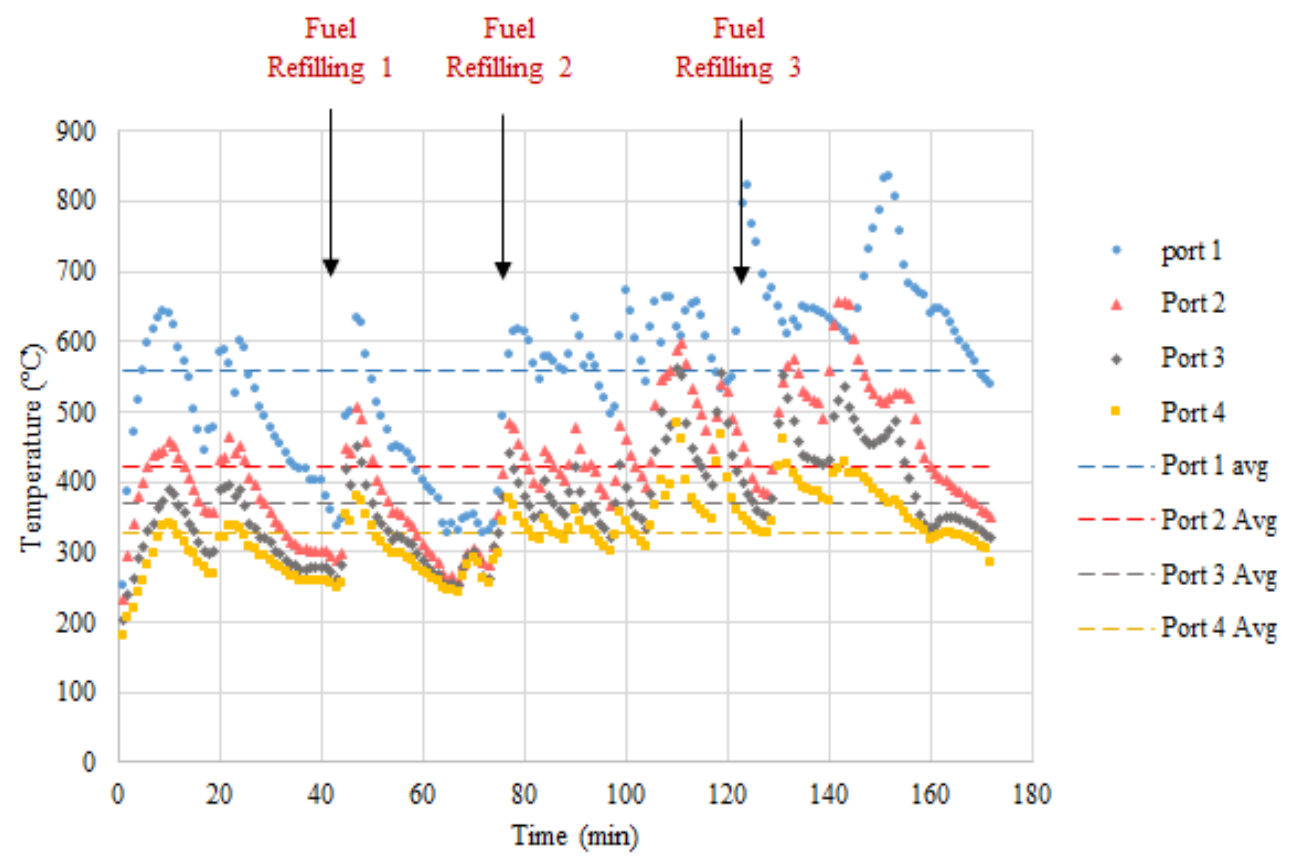

Figure 4. Temperature variations of the DDDC reactor

Table 2. Temperature requirements for different stages of the pyrolysis process (Basu, 2013)

\begin{tabular}{|c|c|c|c|c|}
\hline $\begin{array}{l}\text { Pyrolysis } \\
\text { stage }\end{array}$ & Process & $\begin{array}{c}\text { Required } \\
\text { temperature }\left({ }^{\circ} \mathrm{C}\right)\end{array}$ & $\begin{array}{l}\text { Port } \\
\text { No }\end{array}$ & $\begin{array}{c}\text { Avg. reactor } \\
\text { temperature }\left({ }^{\circ} \mathrm{C}\right)\end{array}$ \\
\hline Drying stage & Removal of $\mathrm{H}_{2} \mathrm{O}$ & $100-150$ & 4 & 330 \\
\hline Initial stage & $\begin{array}{l}\text { Removal of } \mathrm{H}_{2} \mathrm{O} \text { and low- } \\
\text { molecular weight gasses } \\
\text { like } \mathrm{CO} \text { and } \mathrm{CO}_{2}\end{array}$ & $100-300$ & 3 & 370 \\
\hline $\begin{array}{l}\text { Intermediate } \\
\text { stage }\end{array}$ & $\begin{array}{l}\text { Production of char, bio-oil } \\
\text { and non-condensable gasses }\end{array}$ & $200-600$ & 2 & 425 \\
\hline Final stage & $\begin{array}{l}\text { Secondary cracking of } \\
\text { volatiles occur producing } \\
\text { secondary char }\end{array}$ & $300-900$ & 1 & 560 \\
\hline
\end{tabular}

Although the average temperatures gradient within the combustion chamber was adequate for the pyrolysis process, the results indicated fluctuations of temperature during operation due to incomplete combustion of paddy husk used as the fuel source at bottom stationary layers 
(Figure 5). Further, half-burned paddy husks were observed in the ash. Consequently, an additional high energy fuel supply, coconut shell $(0.77 \mathrm{~kg} / \mathrm{hr})$ was required to maintain optimum temperatures for the pyrolysis process. Hence, maintenance of a thick coconut shell charcoal layer at the bottom of the combustion chamber could be suggested to minimize temperature fluctuations observed during the pyrolysis process.

\section{Syngas composition and energy value}

The summery of the obtained syngas analysis results are shown in the Table 3 . The total volume of combustible gasses $\left(\mathrm{CO}, \mathrm{CH}_{4}\right.$ and $\left.\mathrm{H}_{2}\right)$ was $33.57 \%$ in the cleaned syngas. The average calorific value was $5.58 \mathrm{MJ} / \mathrm{m}^{3}$, which was higher than the value reported $(5.13$ $\mathrm{MJ} / \mathrm{m}^{3}$ ) by Atae, et al. (2012). High energy content of the produced syngas increases its ability to use as a fuel. Also, the low amount of $\mathrm{O}_{2}$ is desirable in industrial operations as it reduces the probability of explosions (Kate and Chaurasia, 2018).

Table 3. Summary of the syngas analysis data

\begin{tabular}{|c|c|c|c|c|c|c|c|c|}
\hline $\begin{array}{l}\text { Gas } \\
\text { type }\end{array}$ & $\begin{array}{c}\text { CO } \\
(\% \mathrm{v} / \mathrm{v})\end{array}$ & $\begin{array}{c}\mathrm{CO}_{2} \\
(\% \mathrm{v} / \mathrm{v})\end{array}$ & $\begin{array}{c}\mathrm{CH}_{4} \\
(\% \mathrm{v} / \mathrm{v})\end{array}$ & $\begin{array}{l}\mathrm{CnH}_{\mathrm{m}} \\
(\% \mathrm{v} / \mathrm{v})\end{array}$ & $\begin{array}{c}\mathrm{H}_{2} \\
(\% \mathrm{v} / \mathrm{v})\end{array}$ & $\begin{array}{c}\mathrm{O}_{2} \\
(\% \mathrm{v} / \mathrm{v})\end{array}$ & $\begin{array}{c}\mathrm{N}_{2} \\
(\% \mathrm{v} / \mathrm{v})\end{array}$ & $\begin{array}{c}\text { Calorific } \\
\text { Value } \\
\left(\mathrm{MJ} / \mathrm{m}^{3}\right)\end{array}$ \\
\hline $\begin{array}{l}\text { Exhaust } \\
\text { gas }\end{array}$ & $\begin{array}{c}0.64 \\
( \pm 0.35)\end{array}$ & $\begin{array}{c}7.21 \\
( \pm 0.21)\end{array}$ & $\begin{array}{c}0.66 \\
( \pm 0.05)\end{array}$ & $\begin{array}{c}0.00 \\
( \pm 0.01)\end{array}$ & $\begin{array}{c}0.00 \\
( \pm 0.18)\end{array}$ & $\begin{array}{c}12.23 \\
( \pm 0.22)\end{array}$ & $\begin{array}{c}79.26 \\
( \pm 0.34)\end{array}$ & $\begin{array}{c}0.34 \\
( \pm 0.08)\end{array}$ \\
\hline $\begin{array}{l}\text { Raw } \\
\text { syngas }\end{array}$ & $\begin{array}{c}20.78 \\
( \pm 0.74)\end{array}$ & $\begin{array}{c}13.30 \\
( \pm 0.29)\end{array}$ & $\begin{array}{c}3.87 \\
( \pm 0.10)\end{array}$ & $\begin{array}{c}0.30 \\
( \pm 0.01)\end{array}$ & $\begin{array}{c}6.91 \\
( \pm 0.26)\end{array}$ & $\begin{array}{c}0.68 \\
( \pm 0.42)\end{array}$ & $\begin{array}{c}54.16 \\
( \pm 0.95)\end{array}$ & $\begin{array}{c}5.34 \\
( \pm 0.18)\end{array}$ \\
\hline $\begin{array}{l}\text { Syngas } \\
\text { after } \\
\text { cleaning }\end{array}$ & $\begin{array}{c}22.76 \\
( \pm 0.10)\end{array}$ & $\begin{array}{c}11.27 \\
( \pm 1.08)\end{array}$ & $\begin{array}{c}3.78 \\
( \pm 0.03)\end{array}$ & $\begin{array}{c}0.31 \\
( \pm 0.00)\end{array}$ & $\begin{array}{c}7.03 \\
( \pm 0.00)\end{array}$ & $\begin{array}{c}0.71 \\
( \pm 1.18)\end{array}$ & $\begin{array}{l}54.14 \\
( \pm 0.2)\end{array}$ & $\begin{array}{c}5.58 \\
( \pm 0.02)\end{array}$ \\
\hline Ref. 01 & 11.51 & 21.43 & - & - & 30.78 & - & 35.27 & 5.13 \\
\hline Ref. 02 & 42.79 & 30.05 & 0.00 & - & 27.16 & 0.00 & - & - \\
\hline
\end{tabular}

Note: standard deviations are provided in brackets, Ref. 01: (Ataei, et al., 2012), Ref. 02: (Kate and Chaurasia, 2018)

It was also observed that the absorbance of $\mathrm{CO}_{2}$ by the bubbling scrubber decreased $\mathrm{CO}_{2}$ percentage from $13.3(\% \mathrm{v} / \mathrm{v})$ to $11.27(\% \mathrm{v} / \mathrm{v})$, which increased the concentrations of useful combustible gasses in the gas mixture. There is a $0.09 \%$ reduction of $\mathrm{CH}_{4}$ in the $\mathrm{Ca}(\mathrm{OH})_{2}$ treated syngas and this could be due to the variation of measured values as mentioned in the Table 3. Additionally, there is a slight water solubility of $\mathrm{CH}_{4}$, though there are no any ionic reactions.

\section{Biochar recovery and the mass balance of the reactor}

The average biochar recovery of the reactor was 31.75\% (dry basis). Natarajan and Ganapathy (2009) reported that average char yield at $550{ }^{\circ} \mathrm{C}$ is about $34 \%$ and $\mathrm{Hsu}$, et al., (2015) reported average char yield of $30.65 \%$ at the temperature $600{ }^{\circ} \mathrm{C}$ and at a feeding rate of $10 \mathrm{~g} / \mathrm{min}$. Thus, the obtained results were within the satisfactory level. The average mass generation/consumption rates obtained during the field trials are given in Table 4. The average moisture content of the used paddy husk was $10 \%$ (wet basis). The mass generation 
rate for the bio oil was calculated referring the oil recovery percentage of $38.8 \%$ for rice husk (Islam, et al., 2011). Syngas yield was calculated assuming all the remaining mass of the feedstock turned into gaseous products. The obtained average biochar production rate was 1 $\mathrm{kg} / \mathrm{hr}$ by consuming $4.42 \mathrm{~kg}$ of paddy husk and $0.77 \mathrm{~kg}$ of coconut shell per hour as fuels.

Table 4. Mass balance for the DDDC reactor

\begin{tabular}{llc}
\hline \multicolumn{1}{c}{ Material } & $\begin{array}{c}\text { Avg. Mass consumption/ generation } \\
\text { rate (kg/hr) }\end{array}$ \\
\hline \multirow{3}{*}{ Inputs } & Feedstock (Paddy husk) & 3.5 \\
& Fuel (Paddy husk) & 4.42 \\
& Fuel (Coconut shell) & 0.77 \\
Outputs & Biochar (31.75\% recovery) & 1 \\
& Syngas (29.45\% recovery) & 0.92 \\
& Bio oil (38.8\% recovery) & 1.22 \\
& Water vapour & 0.35 \\
\hline
\end{tabular}

\section{Energy balance of the reactor}

The calorific value of each feedstock and fuel materials were obtained through literature data (Ma et al., 2015; Islam et al., 2011) and the syngas calorific value was obtained through direct measurements (Table 3 ). The table 5 shows the energy content of each material calculated using the equation 2 .

Table 5. Energy values for each biomass material in the pyrolysis process

\begin{tabular}{lccc}
\hline Material & $\begin{array}{c}\text { Mass flow rate } \\
\text { (kg/hr) }\end{array}$ & $\begin{array}{c}\text { Calorific value } \\
\text { (MJ/kg) }\end{array}$ & $\begin{array}{c}\text { Energy content } \\
\text { (MJ/hr) }\end{array}$ \\
\hline $\begin{array}{l}\text { Dry feedstock (Paddy } \\
\text { husk) }\end{array}$ & 3.15 & 12.85 & 40.48 \\
Dry fuel (Paddy husk) & 3.98 & 12.85 & 51.14 \\
Fuel (Coconut shell) & 0.77 & 20.80 & 16.02 \\
Biochar & 1.00 & 12.35 & 12.35 \\
Bio-oil & 1.22 & 16.00 & 19.52 \\
Syngas & 0.92 & 5.34 & 4.91 \\
\hline
\end{tabular}

† Source: Ma et al., (2015); Islam et al., (2011)

According to the above data, the energy balance calculation was done with $60 \%$ and $80 \%$ combustion efficiencies for rice husk and coconut shells, respectively. By substituting the respective values for the equation 3 , energy loss through the reactor was calculated as below.

$$
\begin{aligned}
{[40.48]+[(51.14 \times 0.6)+(16.02 \times 0.8)] } & =[12.35]+[4.91]+[19.52]+[\text { Losses }] \\
\text { Energy loss from the reactor } & =47.2 \mathrm{MJ} / \mathrm{hr}
\end{aligned}
$$

The energy losses through the reactor accounts $56.2 \%$ of the total energy input, which can be reduced by proper insulation with high temperature ceramic concrete cover. 


\section{CONCLUSIONS}

A novel Downdraft Double Chamber pyrolysis reactor (DDDC) was designed and successfully tested for continuous operation to produce paddy husk biochar and syngas. The performance evaluation showed a satisfactory biochar recovery rate $(31.75 \%)$ and syngas energy value $\left(5.53 \mathrm{MJ} / \mathrm{m}^{3}\right)$. The major issue with the reactor was the temperature fluctuations occurred during the continuous operations due to low energy value of paddy husk and high energy losses. The mass and energy balance assessment suggested that proper insulation, change of fuel: air ratio and maintenance of a thick charcoal bed at the bottom of the combustion chamber could contribute to maintain a constant temperature during continuous operations. Thus, the design and testing of pilot scale DDDC reactor showed the potential of optimizing and upscaling a continuous mode paddy husk pyrolysis reactor for industrial applications.

\section{ACKNOWLEDGEMENT}

Funding provided by National Research Council of Sri Lanka under the target oriented grant research grant No. TO 16-07 is gratefully acknowledged.

\section{REFERENCES}

Amarasinghe, H., Gunathilake, S. and Karunarathna, A. (2016). Ascertaining of optimum pyrolysis conditions in producing refuse tea biochar as a soil amendment. Procedia Food Sci. 6, 97-102.

Ataei, A., Azimi, A., Kalhori, S.B., Abari, M.F. and Radnezhad, H. (2012). Performance analysis of a co-gasifier for organic waste in agriculture. Int. J. Recycl. Org. Waste Agri. $1(1), 6$.

Aziz, M. A., Rahman, M. and Molla, H. (2018). Design, fabrication and performance test of a fixed bed batch type pyrolysis plant with scrap tire in Bangladesh. J. Radiat. Res. Appl. Sci. 2018, 1-6.

Bandara, M.R.I.A., Basnayake, BF.A., Ariyawansha, R.T.K. and Senevirathne, S.A.D.N. (2016). Performance evaluation of a refuse derived fuel gasifier for power generation at Gohagoda, Kandy. In: Proceedings of 12th International Conference of the International Institute for Infrastructure Resilience and Reconstruction (IIIRR), Kandy, Sri Lanka on $5^{\text {th }}$ $7^{\text {th }}$ August, 2016. 96-104.

Basu, P. (2010). Pyrolysis and Torrefaction BT - Biomass Gasification and Pyrolysis. 65-96. Academic Press, Boston, USA.

Boateng, A.A., Daugaard, D.E., Goldberg, N.M. and Hicks, K.B. (2007). Bench-scale fluidized-bed pyrolysis of switchgrass for bio-oil Production. Ind. Eng. Chem. Res. 46(7), 1891 - 1897.

Brassard, P., Godbout and Raghavan, V. (2017). Pyrolysis in auger reactors for biochar and bio-oil production: A review. Biosyst. Eng. 161, 80 - 92. 
Brown, J.N. (2009). Development of a lab-scale auger reactor for biomass fast pyrolysis and process optimization using response surface methodology. MSc thesis. Lowa State University. Lowa.

Dharmakeerthi, R., (2014). A simple and low cost stove to produce biochar while generating bioenergy. Sri Lanka, Patent No. 16804.

Dharmakeerthi, R., Chandraisiri, J. and Edirimanne, V. (2014). A carbon negative technique to produce biochar. Sri Lanka, Patent No. 16295.

Hsu, C.P., Huang, A.N. and Kuo, H.P. (2015). Analysis of the rice husk pyrolysis products from a fluidized bed reactor. Procedia Eng. 102, 1183 - 1186.

Islam, M.S., Jamal, M.S., Sujan, S.M.A., Ismail, M., Miah, M.Y. and Saha, M. (2011). Bio oil from pyrolysis of rice husks. Biofuels. 2(1), 1-7.

Kate, G.U. and Chaurasia, A.S. (2018). Gasification of rice husk in two-stage gasifier to produce syngas, silica and activated carbon. Energy Sources, Part A: Recover. Util. Environ. Eff. 40(4), 466-471.

Kersten, S.R.A., Wang, X., Prins, W. and Van Swaaij, W.P.M. (2005). Biomass pyrolysis in a fluidized bed reactor. Part 1: literature review and model simulations. Ind. Eng. Chem. Res. 44(23), 8773 - 8785.

Ma, Z., Ye, J., Zhao, C. and Zhang, Q. (2015). Gasification of rice husk in a downdraft gasifier: The effect of equivalence ratio on the gasification performance, properties, and utilization analysis of by-products of char and tar. Bio Resources. 10(2), 2888-2902.

Mullen, C.A., Boateng, A.A., Goldberg, N.M., Lima, I.M., Laird, D.A. and Hicks, K.B. (2010). Bio-oil and bio-char production from corn cobs and stover by fast pyrolysis. Biomass and bioenergy. 34(1), 67-74.

Natarajan, E. and Ganapathy, E.S. (2009). Pyrolysis of rice husk in a fixed bed reactor. World Acad. Sci. Eng. Technol. 56, 504 - 508.

Panwar, N.L. (2009). Design and performance evaluation of energy efficient biomass gasifier based cook stove on multifuels. Mitig. Adapt. Strat. Gl. 14(7), 627-633.

Putun, A.E., Apaydın, E. and Putun, E. (2004). Rice straw as a bio-oil source via pyrolysis and steam pyrolysis. Energy. 29, 2171-2180.

Sylva, K., Udalamattha K., Bogahawatta, S., Senanayake, N. and Abeyweera, R. (2014). Dendro power generation in Sri Lanka - Successes, failures and policies. Sri Lanka energy managers association (SLEMA) Journal. 17, 20-26.

Wagenaar, B.M., Prins, W. and Van Swaaijt, W.P.M. (1995). Pyrolysis of biomass in the rotating cone reactor: modelling and experimental justification. Chem. Eng. Sci. 49, 51095126. 
Westerhout, R.W.J., Waanders, J., Kuipers, J.A.M. and Van Swaaij, W.P.M. (1998). Recycling of polyethene and polypropene in a novel bench-scale rotating cone reactor by high-temperature pyrolysis. Ind. Eng. Chem. Res. 37, 2293-2300.

Woolf, D., Lehmann, J., Joseph, S., Campbell, C., Christo, F. C. and Angenent, L. T. (2017). An open-source biomass pyrolysis reactor. Biofuel Bioprod. Bior. 11(6), 945-954. 